\title{
The Attitude of Nursing Students Towards Mobile Learning
}

\author{
Dilek AKTAŞ ${ }^{1}$ (D) Gülay YAZICI ${ }^{2}$ iD Sema KOÇAŞLI ${ }^{3}$ iD Kübra YILMAZ $^{4}$ iD \\ ${ }^{1}$ Ankara Yıldırım Beyazıt Üniversitesi, Sağlık Bilimleri Fakültesi, Hemşirelik Bölümü, Ankara, Türkiye \\ dlkakts88@gmail.com (Sorumlu Yazar/Corresponding Author) \\ ${ }^{2}$ Ankara Yıldırım Beyazıt Üniversitesi, Sağlık Bilimleri Fakültesi, Hemşirelik Bölümü, Ankara, Türkiye \\ gtanrikulu61@gmail.com \\ ${ }^{3}$ Ankara Yıldırım Beyazıt Üniversitesi, Sağlık Bilimleri Fakültesi, Hemşirelik Bölümü, Ankara, Türkiye \\ skocasli@yahoo.com.tr \\ ${ }^{4}$ Ankara Yıldırım Beyazıt Üniversitesi, Sağlık Bilimleri Fakültesi, Hemşirelik Bölümü, Ankara, Türkiye \\ kbrylmz3@hotmail.com
}

\begin{tabular}{|c|c|}
\hline Article Info & ABSTRACT \\
\hline $\begin{array}{l}\text { Article History } \\
\text { Received: } 26.03 .2021 \\
\text { Accepted: } 13.07 .2021 \\
\text { Published: } 25.08 .2021\end{array}$ & $\begin{array}{l}\text { Purpose: This study was conducted to determine the attitudes of nursing students towards mobile learning. } \\
\text { Method: This descriptive study was conducted with } 369 \text { students studying at the nursing department of a } \\
\text { university who voluntarily accepted to participate in the study. Personal Information Form and "Attitude Scale } \\
\text { Towards Mobile Learning" were used to collect the data. Ethics committee permission, institution permit and } \\
\text { students informed consents were obtained for the implementation of the research. Data was analyzed in IBMM } \\
\text { SPSS Statistics } 22 \text { program. In data analysis, percentage, frequency, and Independent Sample t-test, Kruskal- } \\
\text { Wallis H, One-Way ANOVA, and Mann-Whitney U Tests were used. } \\
\text { Results: All students used cellphone/smartphone. More than half of them }(64.0 \%) \text { thought mobile learning was } \\
\text { useful for both theoretical and practical lessons. Most of the students ( } 88.6 \%) \text { were found to use mobile devices } \\
\text { for research purpose. Attitudes of the students towards mobile learning were determined at the moderately } \\
\text { positive level (Total score: } 160.15 \pm 23.79) \text {. It was found that those who think that mobile learning is not useful } \\
\text { in their lessons have a statistically significant lower total score and the satisfaction sub-dimension score than } \\
\text { others (p: 0.000; p: 0.000). } \\
\text { Conclusions and Suggestions: Students' widely usage of mobile devices especially smartphones, their } \\
\text { enthusiasm to benefit from them and positive attitudes towards mobile learnings indicate mobile devices can } \\
\text { be used in nursing education. In this context, it is recommended that related research about mobile device usage } \\
\text { in nursing education must be increased and studies which research students' experiences in this field must be } \\
\text { conducted. }\end{array}$ \\
\hline
\end{tabular}

\section{Hemşirelik Öğrencilerinin Mobil Öğrenmeye Yönelik Tutumu}

\begin{tabular}{|c|c|}
\hline Makale Bilgileri & $\ddot{\mathbf{O Z Z}}$ \\
\hline Makale Geçmişi & $\begin{array}{l}\text { Amaç: } \mathrm{Bu} \text { araştırma hemşirelik öğrencilerinde mobil öğrenmeye yönelik tutumu belirlemek amacıyla } \\
\text { gerceklestirildi. }\end{array}$ \\
\hline Gelis: 26.03 .2021 & Yöntem: Tanımlayıcı arastırma olarak yapılan bu calıșma bir üniversitenin hemsirelik bölümünde eğitim gören \\
\hline Kabul: 13.07.2021 & araştırmaya katılmayı gönüllü kabul eden 369 öğrenci ile gerçekleştirildi. Verilerin toplanmasında kişisel \\
\hline Yayın: 25.08.2021 & $\begin{array}{l}\text { bilgiler formu ve "Mobil Öğrenmeye Yönelik Tutum Ölçeği" kullanıldı. Araştırmanın uygulanabilmesi için } \\
\text { etik kurul izni, kurum izni ve öğrencilerin aydınlatılmış onamları alındı. Veriler IBMM SPSS Statistics } 22\end{array}$ \\
\hline Anahtar Kelimeler: & $\begin{array}{l}\text { programında değerlendirildi. Verilerin değerlendirilmesinde yüzde, frekans, Independent Sample t-test, } \\
\text { Kruskal-Wallis H, One-Way ANOVA, and Mann-Whitney U Tests kullanıldı. }\end{array}$ \\
\hline Hemşirelik Öğrencisi, & Bulgular: Öğrencilerin tamamı cep telefonu/akıllı telefon kullanmaktadır. Öğrencilerin yarıdan fazlası \\
\hline & (\%64.0) mobil öğrenmenin hem teorik hem de pratik dersler için yararlı olduğunu düşünmektedir. Öğrencilerin \\
\hline & $\begin{array}{l}\text { çoğunluğu (\%88.6) mobil cihazları araştırma amacıyla kullandığı saptandı. Öğrencilerin mobil öğrenmeye } \\
\text { yönelik tutumları orta düzeyde olumlu düzeyde belirlendi(Toplam Puanı: } 160.15 \pm 23.79 \text { ). Mobil öğrenmenin } \\
\text { derslerinde yararlı olmadığını düşünenlerin mobil öğrenmeye yönelik tutum ölçeği toplam puanının ve } \\
\text { memnuniyet alt boyut puanının diğerlerinden istatistiksel olarak anlamlı düzeyde daha düşük olduğu saptandı } \\
\text { (p:0.000; p:0.000). }\end{array}$ \\
\hline & $\begin{array}{l}\text { Sonuç ve Öneriler: Öğrencilerin mobil cihazları, özellikle akıllı telefonları yaygın olarak kullanmaları, } \\
\text { bunlardan faydalanma istekleri ve mobil öğrenmeye yönelik olumlu tutumları, mobil cihazların hemşirelik } \\
\text { eğitiminde kullanılabileceğini göstermektedir. Bu bağlamda, hemşirelik eğitiminde mobil cihaz kullanımı ile } \\
\text { ilgili araştırmaların artırılması ve öğrencilerin bu alandaki deneyimlerini araştıran çalışmaların yapılması } \\
\text { önerilmektedir. }\end{array}$ \\
\hline
\end{tabular}

Atıf/Citation: Aktaş, D., Yazıcı, G., Koçaşlı, S. \& Yılmaz, K. (2021). The attitude of nursing students towards mobile learning. Genel Sağllk Bilimleri Dergisi, 3(2), 133-142. 


\section{INTRODUCTION}

Mobile learning defines as flexible learning occures through mobile devices that we carry daily such as smartphone and tablet and can be shaped according to the needs of learners (Sirakaya \& Sirakaya Alsancak, 2017). Importance of mobile device in our lives has raised with developing technology aiming at easing our access to information (A $\breve{g c a} \&$ Bağc1, 2013). Usage of a mobile device as a learning tool can increase students' motivation and their academic success, form a positive attitudes towards lesson, and ensure their control on learning process (Erdoğdu \& Şahin, 2016; Koohestani et al., 2019; Li et al., 2018; Sönmez \& Çapuk, 2019). Furthermore, students apprise mobile learning as innovative and entertaining (Ağca \& Bağc1, 2013).

The use of mobile devices in health education is increasing (Klímová, 2018). Mobile devices allow students to access easily to evidence-based studies, guidelines, drug guidelines, e-books, and applications which develop their clinical practice and experience, increase students' knowledge and skill levels and improve learning outcomes (Klímová, 2018; Li et al., 2018; Şahin \& Başak, 2017). In the meta-analysis conducted by Kim and Park (2019), it was concluded that smartphone-based mobile learning in nursing education was effective in improving students' attitudes towards learning and had a positive effect on knowledge, skills, and confidence in learning. In a study assessing nursing students' experience of using PDA (Personal Digital Assistant) in clinical practice, it was observed that more than half of the students stated that using PDA facilitated using drug applications and notes writing as well as saving their time in clinical applications (Johansson et al., 2012). Also, in the study carried out by Kim et al. (2017), it was concluded that the education given to students by mobile application increased the application skill.

Being aware of new trends which can affect nursing education and researching a way to benefit positively from them are very important (Şahin \& Başak, 2017). However, the spread of mobile learning environment depends on people's adaption and acceptation of technology (Menzi et al., 2012). Determining the attitudes of students towards learning through mobile devices is important for the success of mobile learning implementation (Demir \& Akpınar, 2016). In this way, an efficient learning environment can be designed according to learners' perception and needs (Elçiçek \& Bahçeci, 2015). So, this study was carried out to determine nursing students' attitudes towards mobile learning.

\section{METHOD}

\section{Research Design}

This research was conducted as a descriptive study to determine nursing students' attitudes towards mobile learning

\section{Research Sample}

All students registered in nursing bachelor program (n:544) were invited to participate in this study. 369 students who voluntarily accepted to participate in the study were included in the study.

\section{Research Instruments and Processes}

Personal Information Form: This form consists of eight questions including items such as students' age, gender, mobile device type, daily internet usage time, and mobile usage purpose.

Attitude Scale Towards Mobile Learning (ASTML): The Attitude Scale Towards Mobile Learning (ASTML) was developed by Demir and Akpınar in 2016 to measure the attitudes of undergraduate students towards mobile learning. ASTML consists of 45 items with 4 dimensions 
(Satisfaction, Impact on Learning, Motivation, and Usefulness) (Cronbach's Alfa: 0.95). The items of the scale are in five-point likert type and are graded as completely agree (5), agree (4), partially agree (3), disagree (2), completely disagree (1). Total score can be calculated by collecting all item scores. The scores of 5., 27., 28., 30., 32., 36., 40. items in the scale are calculated by reversing. A person with a positive attitude can get at most 225 scores from this scale. The lowest score which can be got from this scale was determined as 45 (Demir \& Akpınar, 2016). In this study, the Cronbach's Alpha was determined as 0.947.

Data collection forms were administered face to face at the end of an appropriate lesson according to the curriculum of the students. Collecting data took approximately 20 minutes for each classroom.

\section{Data Analysis}

Data was analyzed by IBMM SPSS Statistics 22 program. In data analysis, percentage, frequency, and mean were used along with Independent Sample t-test, Kruskal-Wallis H, One-Way ANOVA, and Mann-Whitney U Tests. Findings were evaluated at $95.0 \%$ confidence interval and the statistical significance was considered at $\mathrm{p}<0.05$.

\section{Ethic}

Ethical committee permission (Date-Decision Number:23.03.2018-74) from University Ethical Committee and official permission from the institution were got to conduct this research. Before collecting data, the aims of the study and the method of completing the scales were explained to the students and written consents and verbal permissions were taken as well.

\section{RESULTS}

Among the nursing students paticipated in this study, $87.8 \%$ were female and $30.6 \%$ were in 3 rd class. According to their statements, it was determined that all of them (100\%) used mobile phones/smartphones, $44.7 \%$ used internet for 4 to 6 hours daily, $88.6 \%$ used mobile devices for research purposes, and $64.0 \%$ thought that mobile learning was useful in both theoretical and practical lessons (Table 1).

Table 1. Descriptive Characteristics of Students (n:369)

\begin{tabular}{lll}
\hline Descriptive Characteristics & N & \% \\
\hline Gender & 324 & 87.8 \\
Female & 45 & 12.2 \\
Male & & \\
\hline Class & 88 & 23.8 \\
$\mathbf{1 .}$ Class & 97 & 26.3 \\
$\mathbf{2 .}$ Class & 113 & 30.6 \\
3. Class & 71 & 19.3 \\
$\mathbf{4 .} \quad$ Class & & \\
\hline Mobile devices owned by students & 369 & 100 \\
Cellphone/ Smartphone & 106 & 28.7 \\
Tablet & 9 & 2.4 \\
Netbook & 74 & 20.1 \\
Notebook & & \\
\hline Average internet usage time & 141 & 38.2 \\
\hline -3 hours & 165 & 44.7 \\
4-6 hours & 49 & 13.3 \\
7-9 hours & 14 & 3.8 \\
\hline
\end{tabular}




\begin{tabular}{llc}
\hline Purpose of using mobile devices & \\
Research & 327 & 88.6 \\
Chat-instant messaging & 313 & 83.5 \\
Watching online videos & 308 & 76.2 \\
Social networks & 281 & 73.7 \\
SMS & 272 & 72.1 \\
File Download (music, video, software, etc.) & 266 & 71.3 \\
Email & 263 & 58.0 \\
Follow the news & 214 & 55.6 \\
Shopping & 205 & 42.5 \\
Banking & 157 & 41.7 \\
File transfer & 154 & 28.2 \\
Playing online games & 104 & 22.2 \\
E-learning & 82 & 13.6 \\
E-book download- reading & 50 & 6.2 \\
Audio-book download-listening & 23 & 3.0 \\
Podcast & 11 & 24.9 \\
Thinking that mobile learning is useful in lessons & & 4.9 \\
Useful in theoretical lessons & 92 & 64.0 \\
Useful in practical lessons & 18 & 6.2 \\
Useful in both theoretical and practical lessons & 236 & 23 \\
Not useful & &
\end{tabular}

Students ASTML mean score was found to be $160.15 \pm 23.79$. Among the subscales of ASTML, the mean score of "satisfaction", "impact on learning" "motivation" and "usefulness" subscales were $70.15 \pm 14.60,44.14 \pm 6.33,24.80 \pm 5.54$ and $21.04 \pm 4.76$ respectively (Table 2 ).

Table 2. ASTML Scores of Students

\begin{tabular}{lllll}
\hline ASTML & Mean $(\overline{\mathbf{X}})$ & $\begin{array}{l}\text { Standart } \\
\text { Deviation(S.D) }\end{array}$ & $\begin{array}{l}\text { Minumum } \\
(\text { Min. })\end{array}$ & $\begin{array}{l}\text { Maksimum } \\
\text { (Max.) }\end{array}$ \\
\hline Total Score & 160.15 & 23.79 & 101.00 & 224.00 \\
Satisfaction & 70.15 & 14.60 & 29.00 & 100.00 \\
Impact on Learning & 44.14 & 6.33 & 24.00 & 55.00 \\
Motivation & 24.80 & 5.54 & 11.00 & 35.00 \\
Usefulness & 21.04 & 4.76 & 7.00 & 35.00 \\
\hline
\end{tabular}

Comparing the students score based on the gender, it was determined that there were statistically significant differences in total scores and satisfaction subscale scores $(Z=-2.478 ; p=0.013, t=-3.369$; $\mathrm{p}=0.001$ ). Men's ASTML total score and satisfaction subscale scores were found to be significantly higher than females (Table 3).

Comparing the students score based on the different class, it was determined that there were statistically significant differences in motivation and usefulness subscale scores $(\chi 2=20.402 ; p=0.000$, $\chi 2=8.081 ; \mathrm{p}=0.044)$. Our result showed that the 1 st class motivation scores were found to be statistically significantly higher than 3 rd class student and 3 rd class student usefulness scores were found to be statistically significantly higher than 1,2, and 4 class students (Table 3 ).

Statistically significant differences were found between the state of considering whether mobile learning is useful in the lessons and the ASTML total score $(\mathrm{F}=17.679 ; \mathrm{p}=0.000)$, satisfaction scores $(\mathrm{F}=18.907 ; \mathrm{p}=0.000)$, learning effect scores $(\chi 2=15.054 ; \mathrm{p}=0.002)$ and motivation scores $(\chi 2=21.702$; $\mathrm{p}=0.000$ ) (Table 3). It was determined that ASTML total scores of those who thought that mobile learning was not useful in their lessons were significantly lower than others. Likewise, it was found that ASTML total scores of those who thought that they were only useful in theoretical lessons were statistically significantly lower than those who thought mobile learning was useful in both theoretical and practical lessons (Table 3).

It was determined that satisfaction score of those who thought that mobile learning was not useful 
in their lessons were significantly lower than others. At the same time, it was determined that the score of the effect of learning in students who thought that mobile learning was not useful in their lessons were statistically significantly lower than those who thought mobile learning was useful in both theoretical and practical lessons (Table 3).

It was determined that motivation subscale score of those who thought that mobile learning was not useful in their lessons were significantly lower than those who thought mobile learning was useful in only practical lessons and those who thought mobile learning was useful both in theoretical and practical lessons. Likewise, It was determined that motivation subscale score of those who thought that mobile learning was useful in only practical lessons were significantly lower than those who thought mobile learning was useful in both theoretical and practical lessons (Table 3).

Comparing the students score based on the average internet use status, it was determined that there were statistically significant differences in satisfaction and effect on learning subscale scores $(\chi 2=8.475 ; p=0.000, \chi 2=11.235 ; p=0.011)$. The satisfaction subscale score of the internet users with an average of 10 hours and above were found to be statistically significantly higher than those using internet for 4-6 hours and 3 hours or less. At the same time, the effect of learning subscale scores of the internet users with an avarege 7-9 hours were found to be statistically significantly higher than those using internet for 4-6 hours and 3 hours or less (Table 3). 
Table 3. Comparing the Descriptive Characteristics of Students with Attitude Scale Towards Mobile Learning Scores

\begin{tabular}{|c|c|c|c|c|c|c|c|c|c|c|c|}
\hline \multirow{3}{*}{$\begin{array}{c}\text { Descriptive } \\
\text { Characteristics }\end{array}$} & \multirow{3}{*}{$\mathbf{N}$} & \multicolumn{10}{|c|}{ ASTML } \\
\hline & & \multicolumn{2}{|c|}{ Satisfaction } & \multicolumn{2}{|c|}{ İmpact on Learning } & \multicolumn{2}{|c|}{ Motivation } & \multicolumn{2}{|c|}{ Usefulness } & \multicolumn{2}{|c|}{ Total Score } \\
\hline & & $\overline{\mathbf{X}} \pm$ S.D. & $\mathrm{M}[\mathrm{IQR}]$ & $\overline{\overline{\mathbf{X}}} \pm$ S.D. & $\mathrm{M}[\mathrm{IQR}]$ & $\overline{\bar{X}} \pm$ S.D. & $\mathrm{M}[\mathrm{IQR}]$ & $\overline{\bar{X}} \pm$ S.D. & M [IQR] & $\overline{\mathbf{X}} \pm$ S.D. & M [IQR] \\
\hline \multicolumn{12}{|l|}{ Gender } \\
\hline Male & 45 & $76.93 \pm 12.08$ & $75.0[16.5]$ & $45.20 \pm 5.74$ & $44.0[9.0]$ & $25.73 \pm 4.50$ & $26.0[6.5]$ & $20.40 \pm 5.93$ & $22.0[9.0]$ & $168.27 \pm 19.21$ & $163.0[23.0]$ \\
\hline & & \multicolumn{2}{|c|}{$\mathrm{t}=-3,369$} & \multicolumn{2}{|c|}{$\mathrm{Z}=-1.186$} & \multicolumn{2}{|c|}{$Z=-1.398$} & \multicolumn{2}{|c|}{$\mathrm{Z}=-0.275$} & $\mathrm{Z}=-2.478$ & \\
\hline \multicolumn{12}{|l|}{ Class } \\
\hline 1.class & 88 & $70.84 \pm 14.61$ & $71.0[18.0]$ & $44.73 \pm 6.19$ & $44.0[9.0]$ & $25.84 \pm 5.44$ & $26.0[6.8]$ & $20.39 \pm 5.22$ & $21.0[7.0]$ & $161.80 \pm 23.63$ & $163.0[24.8]$ \\
\hline 2.class & 97 & $69.22 \pm 15.59$ & $67.0[19.5]$ & $43.53 \pm 6.28$ & $43.0[9.0]$ & $24.41 \pm 5.59$ & $25.0[7.0]$ & $20.07 \pm 4.61$ & $21.0[5.0]$ & $157.23 \pm 24.47$ & $155.0[32.5]$ \\
\hline 3.class & 113 & $69.28 \pm 13.40$ & $70.0[18.0]$ & $44.20 \pm 6.28$ & $43.0[10.0]$ & $24.03 \pm 5.47$ & $24.0[8.0]$ & $22.68 \pm 4.06$ & $22.0[4.0]$ & $160.19 \pm 23.64$ & $161.0[28.5]$ \\
\hline \multirow[t]{2}{*}{ 4.class } & 71 & $71.99 \pm 15.11$ & $73.0[20.0]$ & $44.20 \pm 6.75$ & $44.0[9.0]$ & $25.31 \pm 5.59$ & $25.0[6.0]$ & $20.58 \pm 4.88$ & $21.0[6.0]$ & $162.07 \pm 23.40$ & $164.0[35.0]$ \\
\hline & & \multicolumn{2}{|c|}{$\begin{array}{l}\mathrm{F}=0.703 \\
\mathrm{p}=0.551\end{array}$} & \multicolumn{2}{|c|}{$\begin{array}{l}\chi^{2}=1.634 \\
\mathrm{p}=0.652\end{array}$} & \multicolumn{2}{|c|}{$\begin{array}{c}\chi^{2}=8.081 \\
\mathbf{p}=\mathbf{0 . 0 4 4} \\
{[\mathbf{1 - 3}]}\end{array}$} & \multicolumn{2}{|c|}{$\begin{array}{c}\chi^{2}=20.402 \\
\mathbf{p}=\mathbf{0 . 0 0 0} \\
{[\mathbf{1 , 2 , 4 - 3}]}\end{array}$} & \multicolumn{2}{|c|}{$\begin{array}{l}\mathrm{F}=0.781 \\
\mathrm{p}=0.505\end{array}$} \\
\hline \multicolumn{12}{|c|}{ Thinking that mobile learning is useful in lessons } \\
\hline Theoretical lessons ${ }^{(1)}$ & 92 & $67.43 \pm 12.48$ & $66.0[15.5]$ & $43.62 \pm 6.23$ & $43.0[8.8]$ & $23.59 \pm 5.17$ & $23.0[6.8]$ & $20.80 \pm 4.43$ & $21.5[5.8]$ & $155.45 \pm 19.24$ & $155.0[24.0]$ \\
\hline $\begin{array}{l}\text { Theoretical and } \\
\text { practical lessons }^{(3)}\end{array}$ & 236 & $73.15 \pm 14.12$ & $73.0[18.8]$ & $44.92 \pm 6.17$ & $44.0[9.0]$ & $26.65 \pm 5.39$ & $25.5[7.5]$ & $21.34 \pm 4.96$ & $21.5[5.0]$ & $165.06 \pm 23.60$ & 164.0 [30.5] \\
\hline Not useful ${ }^{(4)}$ & 23 & $51.87 \pm 12.24$ & $48.0[20.0]$ & $40.35 \pm 6.98$ & $40.0[9.0]$ & $20.78 \pm 6.29$ & $21.0[11.0]$ & $18.87 \pm 3.83$ & $19.0[5.0]$ & $131.87 \pm 19.24$ & 126.0 [24.0] \\
\hline & & \multicolumn{2}{|c|}{$\begin{array}{c}\mathrm{F}=18.907 \\
\mathbf{p}=\mathbf{0 . 0 0 0} \\
{[\mathbf{1 , 2 , 3 - 4}][\mathbf{1 - 3}]}\end{array}$} & \multicolumn{2}{|c|}{$\begin{array}{c}\chi^{2}=15.054 \\
\mathbf{p}=\mathbf{0 . 0 0 2} \\
{[\mathbf{3}-\mathbf{4}]}\end{array}$} & \multicolumn{2}{|c|}{$\begin{array}{c}\chi^{2}=21.702 \\
\mathbf{p}=\mathbf{0 . 0 0 0} \\
{[\mathbf{1 - 3}][\mathbf{2 , 3 - 4}]}\end{array}$} & \multicolumn{2}{|c|}{$\begin{array}{l}\chi^{2}=7.816 \\
\mathrm{p}=0.050\end{array}$} & $\begin{array}{r}\mathrm{F}= \\
\mathrm{p}= \\
{[1,2,3}\end{array}$ & $\begin{array}{l}79 \\
0 \\
1-3]\end{array}$ \\
\hline Average internet usag & time & & & & & & & & & & \\
\hline 0-3 hours & 141 & $69.01 \pm 14.90$ & $67.0[18.5]$ & $43.48 \pm 6.34$ & $43.0[9.0]$ & $24.71 \pm 5.83$ & $24.0[8.0]$ & $21.18 \pm 4.45$ & $21.0[5.0]$ & $158.38 \pm 24.96$ & $157.0[33.0]$ \\
\hline 4-6 hours & 165 & $69.53 \pm 14.89$ & $70.0[18.5]$ & $43.94 \pm 6.14$ & $43.0[7.0]$ & $24.42 \pm 5.35$ & $25.0[7.0]$ & $21.48 \pm 4.55$ & $22.0[6.5]$ & $159.38 \pm 23.92$ & 161.0 [31.0] \\
\hline 7-9 hours & 49 & $73.31 \pm 12.35$ & $72.0[17.5]$ & $45.96 \pm 6.68$ & $46.0[8.5]$ & $25.45 \pm 4.99$ & $25.0[7.0]$ & $20.08 \pm 5.48$ & $21.0[7.0]$ & $164.80 \pm 19.78$ & 163.0 [29.0] \\
\hline 10 hours and more & 14 & $78.07 \pm 13.38$ & 81.0 [20.5] & $44.07 \pm 6.11$ & $44.5[9.5]$ & $28.07 \pm 6.04$ & $28.5[11.8]$ & $17.86 \pm 6.37$ & $18.0[10.8]$ & $171.07 \pm 19.99$ & $172.5[28.8]$ \\
\hline & & $\begin{array}{r}\chi^{2}= \\
\mathbf{p}= \\
{[1}\end{array}$ & & $\begin{array}{r}\chi^{2}=1 \\
\mathbf{p}= \\
{[\mathbf{1}}\end{array}$ & & $\begin{array}{l}\chi^{2}= \\
\mathrm{p}=0\end{array}$ & & $\begin{array}{l}\chi^{2}= \\
\mathrm{p}=0\end{array}$ & & & \\
\hline
\end{tabular}

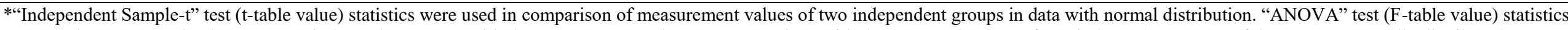

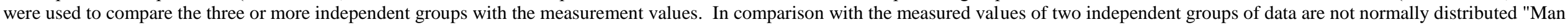

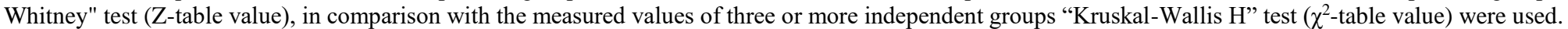




\section{DISCUSSION}

This study was carried out to determine nursing students' attitudes towards mobile learning. Most of the students participating in the study are female. All students have at least one mobile device.

The internet has become an integral part of our lives along with technological development. According to data of the Turkish Statistical Institute (TUIK), the usage of the internet is increasing every day. The rate of internet usage in Turkey has increased from $66.8 \%$ to $72.9 \%$ since 2017 to 2018 (Turkish Statistical Institute [TUIK], 2018). Turnbull et al. (2018) showed that $53.6 \%$ of students used internet for about 5 hours per day. Also, Geçer and İra (2015) stated that $17.3 \%$ of students used internet for 3 hours and $25.4 \%$ used it for 4 hours or more daily. Öksüz et al. (2018) showed that $28.3 \%$ of nursing students used internet for about 3-6 hours a day. In other study conducted with nursing students showed that $60.0 \%$ of them used internet 5 hours or more a day (Abdelgany et al., 2018). In our study, it was concluded that nursing students used the internet between 4 and 10 hours. Considering that all students have smart phones in our study, it is thought that the internet was available 24 hours a day with smart phones.

Today, mobile devices are used for many purposes. In the study of Aguilera-Manrique et al. (2018), 91.8\% of the nursing students stated that they used smartphones for whatshapp, $60.9 \%$ for social networking, and $43.1 \%$ for internet searches. In the study conducted by Koç et al. (2018) with nursing students, it was stated that $95.24 \%$ of students used smart devices for communication and chat, $51.43 \%$ for research and homework, $60.95 \%$ for listening and watching music or movies. Bramlları and Sala (2017) found out that $84.5 \%$ of university students use internet for social media, $42.0 \%$ for updating information, $45.0 \%$ for e-mail, and $43.5 \%$ for online shopping daily. In addition, it was found that $88.0 \%$ of the students stated that the internet improved their studies, and $75.8 \%$ of them said that it helped them to access to detailed information on different subjects through videos and online education. In this study, it was seen that $88.6 \%$ of the students used mobile devices for researching, $84.8 \%$ for instant messaging, and $83.5 \%$ for watching video. These findings indicate that students use mobile devices actively for both social and school life.

Since mobile learning contributes to gaining and developing knowledge and skills and promoting constructivist learning, mobile devices are expected to affect nursing education positively (Guo et al., 2015; Klímová, 2018; Zayim \& Özel, 2015). Therefore, mobile technology has been used in nursing education as an additional tool without any time and space limitation to improve students' clinical practice and experience in many cases (Guo et al., 2015; Patil et al., 2016). The literature indicated that educations with mobile devices affect learning new medical procedures, gaining new skills, increasing knowledge level (Davis et al., 2012; FernándezLao et al., 2016; De Sena et al., 2013; Yoo \& Lee, 2015). In the study of Patil et al. (2016) with medical students, $72.0 \%$ of the students stated that they think that mobile learning provides efficiency in learning. Besides, in the study of Zayim and Özel (2015), 67.0\% of nursing students stated that they are ready for education with mobile learning across the country. Another similare study conducted by O'Connor and Andrews in 2018 to evaluate the use of mobile phones and mobile applicaton in clinical nursing education. Their result showed that $62.0 \%$ of the students considered mobile applications a useful learning tool, $63.0 \%$ of them stated that it improved their nursing knowledge, $56.0 \%$ of them said that it improve their confidence in clinical practice, and $56.0 \%$ stated that it improved their clinical decision making (O'Connor \& Andrews, 2018). Similarly, most of the student (64.0\%) in our study thought that mobile learning was useful for both theoretical and practical lessons.

Students enthusiasm to use mobile learning in their lessons has a positive effect on using a mobile device or mobile application as an education tool (Briz-Ponce et al., 2016). Additionally, students' positive attitudes and perceptions of mobile learning can benefits students which potentially improve their clinical competence, selfconfidence, and theoretical knowledge (Koohestani et al., 2018). However, the adoption of mobile learning is crucial for students and educators to accept or reject it (Hamidi \& Chavoski, 2018). Nassuora (2013) stated that positive attitude toward mobile learning was very important in creating behavioral change for usage of mobile learning. In a study which was conducted on medicine students by Briz-Ponce et al. (2016), it was determined that students perceived mobile learning moderately positive and had a mid-level of enthusiasm to adopt it. Moreover, it 
was stated that $57.0 \%$ of the students were quite enthusiastic to use mobile learning and $40.5 \%$ recommended it as well. In our study, students' attitude towards mobile learning can be considered as a moderate level (Mean Score: $160.15+23.79$ ). Additionally, satisfaction, motivation, and effect on learning subscales scores of the students who thought that mobile learning was not useful in their classes were found to be significantly lower than others (respectively p:0.000, p:0.000, p:0.002). At the same time, motivation sub-dimension score of students who thought that mobile learning was useful for both theoretical and practical lessons was found to be significantly higher than the score of those who thought it was only useful in theoretical lessons. So, it can be concluded that mobile learning method can be used in nursing education.

\section{CONCLUSION AND RECOMMENDATIONS}

Result showed that all nursing students used cell phone or smartphone. Most of the students thought that mobile learning can be useful for both theoretical and practical lessons. Additionally, students were found to have a mid-level positive attitude towards mobile learning. Students' usage of the mobile device especially smartphones and their enthusiasm to benefit from them and having a positive attitude toward mobile learning indicated that mobile devices can be useful in nursing education.

Increasing the quality of nursing education is very important in the development of the nursing profession. Therefore, it is necessary to follow the innovations for the education of students and to apply them correctly. The use of mobile devices and the internet, which have become a part of daily life, will be a step in increasing the success of students. In this context, it is recommended that increase studies on the use of mobile devices in nursing education, conduct studies that include the examination of students 'mobile learning experiences, and organize training programs that will increase students' awareness on this issue.

\section{Funding Sources}

No financial support was received in the study

\section{Conflict of Interest}

The authors declare that are no conflict of interests.

\section{Author Contributions}

Design: D.A., G.Y.; Data collection or processing: D.A., G.Y., S.K.; Analysis or interpretation: K.Y., D.A., G.Y., S.K.; Literature search: K.Y., D.A., S.K.; Writing: K.Y., D.A., S.K.

\section{REFERENCES}

Abdelgany, H.Y., Shalaby, M.H., Elattar, N.F. (2018). Problematic internet use and psychological problems among Faculty of Nursing Students Benha University. Tanta Scientific Nursing Journal, 14(1), 7-30. https://doi.org/10.21608/TSNJ.2018.71024

Aguilera-Manrique G, Márquez-Hernández VV, Alcaraz-Córdoba T, Granados-Gámez G, Gutiérrez-Puertas V, GutiérrezPuertas L. (2018). The relationship between nomophobia and the distraction associated with smartphone use among nursing students in their clinical practicum. PLoS One, 13(8), 1-14. https://doi.org/10.1371/journal.pone.0202953

Ağca, R.K., \& Bağc1, H. (2013). Students views of mobile tools usage in education. Journal of Research in Education and Teaching, 2(4), 295-302. http://www.jret.org/FileUpload/ks281142/File/32.agca.pdf

Braimllar1, A., \& Sala E. (2017). Internet use for learning by the undergraduate students of University of Tirana in Albania. 8th International Conference "Information Systems and Technology Innovations: Fostering the As-AService Economy", International Conference Proceedings, Tirana, Albania, 23-24 June.

Briz-Ponce, L., Juanes-Méndez, J.A., García-Peñalvo, F.J., Pereira, A. (2016). Effects of Mobile Learning in Medical Education: A Counterfactual Evaluation. J Med Syst., 40(6), 131-136. https://doi.org/10.1007/s10916-016-0487-4

Davis, J.S., Garcia, G.D., Wyckoff, M.M., Alsafran, S., Graygo, J.M., Withum, K.F., Schulman, C.I. (2012). Use of mobile learning module improves skills in chest tube insertion. J Surg Res., 177(1), 21-26. https://doi.org/10.1016/j.jss.2012.03.022 
De Marcos Ortega, L., Barchino Plata, R., Jiménez Rodríguez, M.L., Hilera González, J.R., Martínez Herráiz, J.J., Gutiérrez de Mesa J.A., Guiterrez Matrinez, J.M., Oton Tortosa, S. (2011). Using M-Learning on nursing courses to improve learning. Comput Inform Nurs., 29(5), 311-317. https://doi.org/10.1097/NCN.0b013e3181fcbddb

De Sena, D.P., Fabricio, D.D., Lopes, M.H., Da Silva, V.D. (2013). Computer-assisted teaching of skin flap surgery: validation of a mobile platform software for medical students. PLoS One, 8(7), 1-6. https://doi.org/10.1371/journal.pone.0065833

Demir, K., \& Akpınar, E. (2016). Development of attitude scale towards mobile learning. Eğitim Teknolojisi Kuram ve Uygulama, 6(1), 59-79. https://dergipark.org.tr/tr/download/article-file/271655

Elçiçek, M., \& Bahçeci, F. (2015). The research of the vocational school student's attitudes towards mobile learning. Sakarya Üniversitesi Ĕ̈itim Fakültesi Dergisi, 30, 17-33. https://dergipark.org.tr/en/download/article-file/115882

Erdoğdu, F., \& Şahin, S. (2016). Yükseköğretimde her yerde öğrenmenin akademik başarı ve motivasyona etkisi. Bilişim Teknolojileri Dergisi, 12(41), 884-924. https://doi.org/10.29228/Joh24764

Fernández-Lao, C., Cantarero-Villanueva, I., Galiano-Castillo, N., Caro-Morán, E., Díaz-Rodríguez, L., Arroyo-Morales, M. (2016). The effectiveness of a mobile application for the development of palpation and ultrasound imaging skills to supplement the traditional learning of physiotherapy students. BMC Med Educ, 16(1), 268-274. https://doi.org/10.1186/s12909-016-0775-1

Geçer, A., \& İra, N. (2015). Examining information in web environment searching and commitment strategies of university students according to demographic variables. Eğitim ve Bilim, 40(179), 383-402. https://doi.org/10.15390/EB.2015.3131

Guo, P., Watts, K., Wharrad, H. (2015). An integrative review of the impact of mobile technologies used by healthcare professionals to support education and practice. Nurs Open, 3(2), 66-78. https://doi.org/10.1002/nop2.37

Hamidi, H., \&Chavoshi, A. (2018). Analysis of the essential factors for the adoption of mobile learning in higher education: A case study of students of the University of Technology. Telematics and Informatics, 35(4), 1053-1070. https://doi.org/10.1016/j.tele.2017.09.016

Johansson, P., Petersson, G., Saveman, B.I., Nilsson, G. (2012). Experience of mobile devices in nursing practice. Nordic Journal of Nursing Research, 32(4), 50-54. https://doi.org/10.1177/010740831203200411

Kim, J.H., \& Park H. (2019). Effects of smartphone-based mobile learning in nursing education: A systematic review and meta-analysis. Asian Nurs Res, 13(1), 20-29. https://doi.org/10.1016/j.anr.2019.01.005

Kim, S.J., Shin, H., Lee, J., Kang, S., Bartlett, R. (2017). A smartphone application to educate undergraduate nursing students about providing care for infant airway obstruction. Nurse Educ Today, 48, 145-52. https://doi.org/10.1016/j.nedt.2016.10.006

Klímová, B. (2018). Mobile learning in medical education. J Med Syst, 42(10), 1-6. https://doi.org/10.1007/s10916-018-1056$\underline{9}$

Koç, A., Tayaz, E., Erdem, Ö., Kurt, B., Öztaş, D. (2018). Evaluation of knowledge and opinions of nursing students about addiction. Ankara Medical Journal, 18(4), 508-518. https://doi.org/10.17098/amj.462916

Koohestani, H.R., Soltani Arabshahi, S.K., Fata, L., Ahmadi, F. (2018). The educational effects of mobile learning on students of medical sciences: A systematic review in experimental studies. $J$ Adv Med Educ Prof, 6(2), 58-69. https://www.ncbi.nlm.nih.gov/pmc/articles/PMC5856906/pdf/JAMP-6-58.pdf

Koohestani, H. R., Arabshahi, S. K. S., Ahmadi, F., \& Baghcheghi, N. (2019). The experiences of healthcare professional students about the educational impacts of mobile learning. The Qualitative Report, 24(7), 1593-1609. https://doi.org/10.46743/2160-3715/2019.3719

Li, K. C., Lee, L. Y. K., Wong, S. L., Yau, I. S. Y., \& Wong, B. T. M. (2018). Effects of mobile apps for nursing students: Learning motivation, social interaction and study performance. Open Learning: The Journal of Open, Distance and eLearning, 33(2), 99-114. https://doi.org/10.1080/02680513.2018.1454832

Menzi, N., Önal, N., Çalışkan, E. (2012). Investigating educational researchers' views of using mobile technologies for educational purposes based on technology acceptance model. Ege Eğitim Dergisi, 13(1), 39-55. https://dergipark.org.tr/en/download/article-file/57007

Nassuora, A. B. (2013). Students acceptance of mobile learning for higher education in Saudi Arabia. American Academic \& $\begin{array}{llll}\text { Scholarly Research } & \text { Journal, } & \text { 4(2), } & \text { 24-30. }\end{array}$ https://citeseerx.ist.psu.edu/viewdoc/download?doi=10.1.1.402.6814\&rep=rep1\&type=pdf

O'Connor, S., \& Andrews, T. (2018). Smartphones and mobile applications (apps) in clinical nursing education: A student perspective. Nurse Educ Today, 69, 172-178. https://doi.org/10.1016/j.nedt.2018.07.013

Öksüz, E., Güvenc, G., Mumcu, S. (2018). Relationship between problematic internet use and time management among nursing students. Computers, Informatics, Nursing, 36(1), 55-61. https://doi.org/10.1097/CIN.0000000000000391

Patil, R.N., Almale, B.D., Patil, M., Gujrathi, A., Dhakne-Palwe, S., Patil, A.R., Gosavi S. (2016). Attitudes and perceptions of medical undergraduates towards mobile learning (M-learning). J Clin Diagn Res, 10(10), JC06-JC10. https://doi.org/10.7860/JCDR/2016/20214.8682

Sirakaya, M., \& Alsancak Sirakaya, D. (2017). An examination of associate degree students' mobile learning attitudes 
according to various variables. Gazi University Journal of Gazi Educational Faculty, 37(3), 1085-114. http://www.gefad.gazi.edu.tr/tr/download/article-file/393073

Sönmez, N., \& Çapuk, S. (2019). Mobil öğrenmenin akademik başarıya etkisi: Bir meta-analiz çalışması. Tarih Okulu Dergisi, 12(41), 884-924. https://doi.org/10.29228/Joh24764

Şahin, G., \& Başak, T. (2017). Mobile learning in nursing "m-learning". Journal of Human Sciences, 14(4), 4480-4490. https://doi.org/10.14687/jhs.v14i4.4891

Turkish Statistical Institute (2018). Household Information Technologies (IT) Usage Survey, 2019. Aviable at: http://www.tuik.gov.tr/PreHaberBultenleri.do?id=30574 (Accessed April 2019)

Turnbull, N., Peltzer, K., Pengpid, S., Low, W.Y., Huu, T.N., Rochmawati, E., Win, H.H. (2018). Pathological internet use and psychosocial risk factors among ASEAN University students. Iranian Journal Of Psychiatry And Behavioral Sciences, 12(1), 1-8. https://dx.doi.org/10.5812/ijpbs.10063

Yoo, I.Y., \& Lee, Y.M. (2015). The effects of mobile applications in cardiopulmonary assessment education. Nurse Educ Today, 35(2), e19-23. https://doi.org/10.1016/j.nedt.2014.12.002

Zayim, N., \& Özel, D. (2015). Factors affecting nursing students' readiness and perceptions toward the use of mobile technologies for learning. Computers, Informatics, Nursing, 33(10), 456-464. https://doi.org/10.1097/cin.0000000000000172 